\title{
Originalism and the Natural Born Citizen Clause
}

Lawrence B. Solum

Georgetown University Law Center, Ibs32@law.georgetown.edu

This paper can be downloaded free of charge from:

https://scholarship.law.georgetown.edu/facpub/859

http://ssrn.com/abstract=1263885

29 Immigr. \& Nationality L. Rev. 593-601 (2008)

This open-access article is brought to you by the Georgetown Law Library. Posted with permission of the author. Follow this and additional works at: https://scholarship.law.georgetown.edu/facpub

Part of the Constitutional Law Commons, Legal History Commons, Legal Theory Commons, and the Rule of Law Commons 


\title{
ORIGINALISM AND THE NATURAL BORN CITIZEN CLAUSE
}

\author{
Lawrence B. Solum* ${ }^{*}$
}

\section{INTRODUCTION}

The U.S. Constitution, Article II, section 1, provides: "No person except a natural born Citizen, or a Citizen of the United States, at the time of the Adoption of this Constitution, shall be eligible to the Office of President." The enigmatic phrase "natural born citizen" poses a series of problems for contemporary originalism. New Originalists, like Justice Scalia, focus on the original public meaning of the constitutional text. The notion of a "natural born citizen" was likely a term of art derived from the idea of a "natural born subject" in English law-a category that most likely did not extend to persons, like Senator McCain, who were born outside sovereign territory. But the Constitution speaks of "citizens" and not "subjects," introducing uncertainties and ambiguities that might (or might not) make McCain eligible for the presidency.

What was the original public meaning of the phrase that establishes the eligibility for the office of President of the United States? There is general agreement on the core of its meaning. Anyone born on American soil whose parents are citizens of the United States is a "natural bom citizen." Anyone whose citizenship is acquired after birth as a result of naturalization is not a natural born citizen. John McCain, born to American parents in the Panama Canal Zone in 1936, had citizenship conferred by statute in 1937, but there is dispute as to whether the statute granted retroactive naturalization or

* Associate Dean for Faculty and Research and John E. Cribbet Professor of Law and Professor of Philosophy at the University of Illinois. Professor Solum is the author of numerous articles on constitutional theory and the philosophy of law.

$\rightarrow \quad$ Suggested citation: Lawrence B. Solum, Commentary, Originalism and the Natural Born Citizen Clause, $107 \mathrm{MrCH}$. L. REv. FTRST IMPRESSIONS 22 (2008), http://www.michiganlawreview. org/firstimpressions/vol 107/solum,pdf.

Pemission is hereby granted to duplicate this paper for scholarly or teaching purposes, inchuing permission to reproduce multiple copies or post on the Intenet for classroom use and to quote extended passages in scholarly work, subject only to the requirement that this copyright notice, the title of the article, and the name of the author be prominently included in the copy or extended excerpt. Permission is hereby granted to use short excerpts (500 words or less each, so long as the total word count of the excerpts does not exceed $50 \%$ of the total word count of this work) with an appropriate citation and without inclusion of a copyright notice. In the event of the death or permanent ineapacity of the author, all claims to copyright in the work are relinquished and the work is dedicated to the public domain in perpetuity. Even if the author is then living, all copyright claims are relinquished as of January 1,2050 . In the event that the relinquishment of copyright is not given legal effect, an unlimited license of all rights to all persons for all purposes is granted as of that date.

A more scholarly version, with complete citations, is available via the Social Science Research Network: Lawrence B. Solum, Originalism and the Natural Bon Citizen Clause, htt p://papers.ssm.com/abstract $=1263885$.

Reprinted from MICHIGAN LAW REVIEW, First Impressions, December 2008, Vol. 107, No. 3. Copyright 2008 by the Michigan Law Review Association. 
whether it merely confirmed preexisting law under which McCain was an American citizen at birth. That leaves John McCain in a twilight zoneneither clearly naturalized nor natural born.

\section{The Problem Posed by the Natural Born Citizen Clause FOR THE NEW ORIGINALISM}

Some constitutional theorists seem to believe that the constitutional text provides only loose constraints on the enterprise of interpretation. Consider the following analysis of the natural born citizen clause by constitutional scholar Michael Dorf, posted at the Dorf on Law blog February 29, 2008:

[1]f one is not burdened by the label of "originalist," then [McCain's eligibility for the presidency] is a pretty easy question. The "natural born citizen" requirement manifests a distrust of the foreign-born that, in a nation of immigrants, can only be derided as repugnant. I both "reject" it and I "denounce" it! It's still part of the Constitution, however, and therefore we need to try to figure out what it means. My frankly normative move would be to limit the damage by limiting the scope of "foreign-born." There's no plausible way to read the provision to permit Schwarzenegger and other naturalized citizens to become President. There is a ready (if not $100 \%$ clearly the original) way to read it to permit Americans born abroad to U.S. parents to become citizens.

Dorf's comments raise an intriguing question: How would an originalist approach the question whether the original meaning of the natural born citizen clause would permit McCain (and others not born of American parents on American soil) to become President? To answer that question, we need first to understand "originalism" itself.

Originalism is an evolving family of constitutional theories. Early originalist theory emphasized the intentions of the framers or ratifiers, provoking a variety of critical reactions. These criticisms set the stage for what is sometimes called "the New Originalism" and is also called "Original Public Meaning Originalism." On June 14, 1986, Justice Scalia gave a speech before the Attorney General's Conference on Economic Liberties suggesting to proponents of originalism that they "change the label from the Doctrine of Original Intent to the Doctrine of Original Meaning." Scalia's speech was the precursor of the view that the "original meaning" of each provision of the Constitution is the public meaning of the text at the time it was framed and ratified.

In addition to the shift from original intentions to original public meaning, some New Originalists have embraced a distinction between "constitutional interpretation," the enterprise of discerning the semantic content or linguistic meaning of the Constitution, and "constitutional construction," tentatively defined as the activity of further specifying constitutional rules when the original public meaning of the text is vague or otherwise underdeterminate. When the linguistic meaning of the constitutional text "runs out," constitutional construction must supplement constitutional interpretation.

The New Originalism played a substantial role in the Supreme Court's recent decision in District of Columbia v. Heller. There, the Court invalidated a District of Columbia statute that prohibited the possession of 
useable handguns in the home on the ground that it violated the Second Amendment to the Constitution. Given the paucity of precedent on the meaning of the "right to keep and bear arms," Heller offered the Court a now-rare opportunity to address the meaning of the constitutional text unencumbered by constraining precedent. The Court reacted by squarely posing a question that has exemplary significance for investigations of the relationship between constitutional theory and constitutional: How should courts determine the meaning of the Constitution in the absence of controlling precedent?

Writing for the Heller majority, Justice Scalia addressed the issue of constitutional method as follows:

In interpreting this text, we are guided by the principle that "[ $[$ ]he Constitution was written to be understood by the voters; its words and phrases were used in their normal and ordinary as distinguished from technical meaning." . . Normal meaning may of course include an idiomatic meaning, but it excludes secret or technical meanings that would not have been known to ordinary citizens in the founding generation.

Public-meaning originalism focuses on the conventional semantic meaning of the text at the time each constitutional provision was adopted. "Meaning" is a notoriously ambiguous term. When we interpret a legal text, we are interested in the "semantic" or "linguistic" meaning - the kind of meaning that definitions try to capture-and not the of purpose or implication of the text. When we determine "conventional" meanings, we look to patterns of usage-as opposed to the intentions of particular authors or speakers. The kind of originalism that focuses on conventional semantic meaning, as determined by usage at the time each provision of the Constitution was drafted and ratified, can be called "semantic oniginalism."

In many (perhaps most) cases, the inquiry into original meaning can proceed clause-by-clause and word-by-word. We determine the conventional semantic meaning of each word and then combine the meanings of individual words into whole clauses using the rules of grammar and syntax. Indeed, this is the method people ordinarily use to understand utterances in any natural language. But applying this method to the natural born citizen clause presents difficulties. The phrase "natural born citizen" seems to have an idiomatic meaning that cannot be derived from the conventional semantic meanings of the individual words "natural," "born" and "citizen." If these same words were used in another context, they might distinguish citizens who were born naturally from those who were born by Cesarean section. Moreover, if the constitution had been adopted more recently, the phrase might have referred to citizens whose birth resulted from "nonnatural" means, such as artificial insemination or other reproductive technologies. In the eighteenth century, the phrase "natural born citizen" seems to have had a meaning that cannot be derived from individual word meanings - violating the principle of compositionality. The relevant unit of meaning is the phrase as a whole.

The notion that phrases acquire meanings that are not reducible to the meanings of the constituent words is familiar to any competent speaker of a natural language such as English. We sometimes call such phrases "idioms." Many idiomatic phrases are in common usage and have conventional seman- 
tic meanings that are accessible to most or all competent English speakers. But some words and phrases are not familiar to all competent speakers. Some of the words and phrases that comprise the constitutional text may be "terms of art," the meanings of which are accessible only to specialized readers. Blackstone put it this way in his Commentaries: terms of art "must be taken according to the acceptation of the learned in each art, trade, and science."

For example, the phrase "letters of marque and reprisal" (from Article I of the Constitution) might not have been familiar to the ordinary citizen when the Constitution was drafted and ratified. Such terms of art create a potential problem for Justice Scalia's definition of "normal meaning," which excluded "technical meanings." If the meaning of the Constitution excludes technical meanings, then any terms of art included in the Constitution would fail to have any meaning at all and constitutional communication would misfire. For example, if the phrase "letters of marque and reprisal" was not "known to ordinary citizens in the founding generations," then that provision of the Constitution would simply be meaningless-if interpretation were limited to "normal meaning."

\section{Finding the Original Meaning of "Natural Born Citizen"}

How can originalists respond to the problem of constitutional terms of art-the use of "technical meanings"? The solution to this problem is to recognize a division of linguistic labor, a concept developed by philosopher Hilary Putnam. The intuitive idea is simple. When members of the general public encounter a constitutional term of art, their understanding of its meaning involves a process of deferral. Consider a situation in which an ordinary citizen reads the phrase "letters of marquee and reprisal," and thinks, "Hmm. I wonder what that means. It sounds like technical legal language to me. If I want to know what it means, I should probably ask a lawyer." This example suggests that ordinary citizens confronted with "technical" language recognize a division of linguistic labor, and defer to the understanding of the term of art that would be the publicly available meaning to those who were members of the relevant group (for example, lawyers) and those who shared the understandings of the members of the relevant group (for example, other citizens who consulted lawyers about the meaning of the term of art).

How does the division of linguistic labor contribute to our understanding of the natural born citizen clause? The phrase "natural born citizen" does not have a distinctive sense in contemporary usage by ordinary citizens. Although the individual words that comprise the phrase have conventional semantic meanings, it is clear that the meaning of the whole phrase cannot be derived from the meanings of the individual words. Of course, it is possible that the phrase "natural born citizen" would have been familiar to most ordinary speakers of American English in the late eighteenth century. But suppose this were not the case. The clause nonetheless could have had a conventional semantic meaning determined by the linguistic practice of those learned in the law in the late eighteenth century — so long as the division of linguistic labor made the technical meaning accessible to ordinary citizens. 
Existing scholarship does not reveal extensive usage of the phrase "natural born citizen" in the founding era, but it was derived from the related phrase "natural born subject," which had a technical meaning in English law and constitutional theory. Those learned in the law in the framing era would have been familiar with Blackstone's Commentaries, which James Madison described (in the Virginia ratifying convention) as "a book which is in every man's hand." Blackstone wrote as follows:

The first and most obvious division of the people is into aliens and naturalborn subjects. Natural-born subjects are such as are born within the dominions of the crown of England, that is, within the ligeance, or as it is generally called, the allegiance of the king; and aliens, such as are born out of it. Allegiance is the tie, or ligamen, which binds the subject to the king, in return for that protection which the king affords the subject. The thing itself, or substantial part of it, is founded in reason and the nature of government; the name and the form are derived to us from our Gothic ancestors.

. .

Allegiance, both express and implied, is however distinguished by the law into two sorts or species, the one natural, the other local; the former being also perpetual, the latter temporary. Natural allegiance is such as is due from all men born within the king's dominions immediately upon their birth. For, immediately upon their birth, they are under the king's protection; at a time too, when (during their infancy) they are incapable of protecting themselves.

When I say, that an alien is one who is born out of the king's dominions, or allegiance, this also must be understood with some restrictions. The common law indeed stood absolutely so; with only a very few exceptions: so that a particular act of parliament became necessary after the restoration, for the naturalization of children of his majesty's English subjects, born in foreign countries during the late troubles. And this maxim of the law proceeded upon a general principle, that every man owes natural allegiance where he is born, and cannot owe two such allegiances, or serve two masters, at once. Yet the children of the king's ambassadors born abroad were always held to be natural subjects: for as the father, though in a foreign country, owes not even a local allegiance to the prince to whom he is sent; so, with regard to the son also, he was held (by a kind of postliminium) to be born under the king of England's allegiance, represented by his father, the ambassador. To encourage also foreign commerce, it was enacted by statute $25 \mathrm{Edw}$. III. st. 2. that all children born abroad, provided both their parents were at the time of the birth in allegiance to the king, and the mother had passed the seas by her husband's consent, might inherit as if born in England: and accordingly it hath been so adjudged in behalf of merchants. But by several more modern statutes these restrictions are still farther taken off: so that all children, born out of the king's ligeance, whose fathers were natural-born subjects, are now natural-born subjects themselves, to all intents and purposes, without any exception; unless their said fathers were attainted, or banished beyond sea, for high treason; or were then in the service of a prince at enmity with Great Britain. 
Blackstone's understanding of the notion of a "natural born subject" is not completely clear or precise. On the one hand, he states "[n]atural-born subjects are such as are born within the dominions of the crown of England," but on the other hand, he suggests "all children, born out of the king's ligeance, whose fathers were natural-born subjects, are now naturalborn subjects themselves, to all intents and purposes." The latter statement might be considered a modification of the first, but the use of the qualifying language "to all intents and purposes" could be read as suggesting that children born to British subjects abroad were granted the rights of natural born citizens, but were not actually "natural born" themselves. For most practical purposes, this fine distinction is irrelevant because the common-law rule could be overruled by statute. However, when this distinction is applied to the natural born citizen clause, it might become important because statutes cannot overrule the Constitution.

Blackstone's understanding derived from the common law, which seems to have originated in Calvin's Case, a decision of the Court of Common Pleas, reported by Lord Coke in 1608. Writing in his 1914 article Natural Born British Subjects at Common Law in an English law journal, F.B. Edwards summarized the complex and difficult opinion:

\footnotetext{
The question before the Court [in Calvin's Case] ... was whether Robert Calvin, the plaintiff, a Scottish Subject of King James I., who was born after James's accession to the English throne, was an alien; the unanimous finding of the judges was that he "was no alien ...." It is important to remember that at the time when that case was decided the feudal or territorial conception of nationality was practically universal throughout the world; or, at least, that that conception was operative in both England and Scotland as far as the acquisition of the local nationality at birth was concerned.
}

The concept of allegiance to the sovereign at birth (as noted by Blackstone), then, was the fundamental criterion for who was-and was not-a natural born subject. The notion of natural born subjects under British law was tied to the idea of natural allegiance to a sovereign. Natural allegiance was based primarily on being born within the territory subject to the sovereign's rules. But it could also be based on being the children of Ambassadors or children of Sovereigns themselves: members of these groups were considered to have a natural allegiance to the sovereign.

What conception of territory, then, underlies the English conception of a natural born subject? Edwards's answer suggests that such territories are limited to the "sovereign's dominions":

There is little difficulty in deciding whether any particular territory forms part of the King's Dominions. It is quite clear that British Protectorates, whether ordinary or colonial, and spheres of influence are not included within the King's Dominions, and that a right to occupy and administer vested in the British Government does not make British the territory affected.

Nor do the Indian allied states come within the boundary of the British Empire. There seems, however, no reason, beyond a purely technical one, why territories held by the British Crown under what either is, or practically is, a lease in perpetuity, should be excluded from this limit. The 


\begin{abstract}
proposition that British Protectorates, and consequently any less interest of the Crown, should be excluded from our definition of the King's protection, is supported by Sir William Anson, who declares that birth within such a region is not sufficient to found a claim for British natural-born status. The real test of whether a given territory is part of the British Dominions is that it must have passed openly, completely, and unequivocally into the possession of the Crown.
\end{abstract}

If the American conception of "natural born citizen" were equivalent to the English notion of a "natural born subject," then it could be argued that only persons born on American soil to American parents would have qualified. This might lead to the conclusion that McCain would not be a natural born citizen under the Constitution because the Panama Canal Zone was not the sovereign territory of the United States but was instead merely subject to U.S. administrative control. On the other hand, the notion of a natural born subject might have been more flexible, encompassing all those who acquired citizenship at birth (as opposed to those whose citizenship was conferred after birth by "naturalization").

So far we have assumed that the conventional meaning of "natural born citizen" for those learned in the law in the eighteenth century was equivalent to the meaning of "natural born subject" in nineteenth century English law. But is this assumption correct? Does the substitution of the term "citizen" for "subject" alter the meaning of the phrase? And if those learned in the law did recognize a difference, what implications does that have for the meaning of the natural born citizen clause?

The language of the Constitution recognizes a distinction between "citizens" and "subjects." For example, Article III, section 2 differentiates "citizens" of the several states from "citizens" or "subjects" of foreign states. In the framing era, these terms reflected two distinct theories of the relationship between individual members of a political community and the state. In feudal or monarchical constitutional theory, individuals were the subjects of a monarch or sovereign, but the republican constitutional theory of the revolutionary and post-revolutionary period conceived of the individual as a citizen and assigned sovereignty to the people.

The distinction between citizens and subjects is reflected in Chief Justice John Jay's opinion in Chisholm v. Georgia, the first great constitutional case decided after the ratification of the Constitution of 1789: " [A]t the Revolution, the sovereignty devolved on the people; and they are truly the sovereigns of the country, but they are sovereigns without subjects ...." Justice James Wilson confirmed Jay's articulation of the opposition between subjects and citizens. Wilson noted that with the exception of Article III, the Constitution refers to "citizens" and "persons," not subjects: "The term, subject, occurs, indeed, once in the instrument; but to mark the contrast strongly, the epithet 'foreign' is prefixed." Both Jay and Wilson's opinions suggest that usage in the founding era reflects a significant conceptual distinction between the words "subject" and "citizen". The term "citizen" reflects the notion that individual citizens are sovereign in a republic, whereas the term "subject" reflects feudal and monarchical conceptions of the lord or monarch as sovereign and the individual as the subject.

This conceptual distinction may be relevant to the original understanding of the American constitutional phrase "natural born citizen," which was 
used instead of the English legal phrase "natural born subject." The notion of a natural born subject may reflect a feudal understanding of political obligation: Those born in the kingdom owed a natural duty of allegiance to their king and were his natural subjects. Given a republican theory of popular sovereignty, citizens are sovereign, and the notion of a "natural born subject" would be anathema. This leaves a gap in the theory of citizenshipa gap that the Constitution fills with the concept of a natural born citizen.

One interpretation of the new term of art, "natural born citizen," is that its content is identical to the content of the old phrase, "natural born subject," with the purely nominal difference in the term ("citizen" versus "subject") used to refer to members of the political community. This could result in the interpretation suggested above-which would limit natural born citizens to persons born of American parents on American soil.

Those leaned in English law, however, understood another aspect of the concept of "natural born subject." Children of the sovereign were natural born subjects wherever their birth occurred. The issue of the king owed a natural obligation to their father; likewise, the children of the king's ambassadors were deemed to owe a similar obligation to their parents' monarch. But in republican theory the people are sovereign, suggesting that the republican conception of natural born citizens would naturally treat the children of citizen-sovereigns as equivalent to the children of a monarchical sovereign or king. This understanding may have been reflected in the first naturalization act of 1790 "An Act to Establish a Uniform Rule of Naturalization," which provided "the children of citizens of the United States, that may be born beyond sea, or out of the limits of the United States, shall be considered as natural bom citizens." Because the First Congress passed this act, it arguably reflects the original understanding of "natural born citizen" as encompassing those born of the citizen-sovereigns on foreign soil. On this interpretation, John McCain would be a natural born citizen of the United States (at least for the purposes of eligibility for the presidency) because the original meaning of that phrase includes all persons born to American citizens.

On the other hand, the language of the $1790 \mathrm{Act}$ might be interpreted differently. The statute is not explicitly phrased in declaratory terms: The phrase "shall be considered as natural born citizens" might have reflected the understanding that the children of American citizens on foreign soil were not actually "natural born," but could be treated as if they were by granting them a legal status that was otherwise identical to that held by those who were "natural born." On this interpretation, McCain would not qualify as a natural born citizen even if a statute had conferred citizenship upon him at birth. Such a conclusion is based on the conventional and widely shared assumption that Congress lacks power to alter the meaning of the Constitution through legislation.

From the point of view of originalist method, the question is how to resolve the conflict between these two interpretations of the clause. The New Originalism suggests that the object of our inquiry should be the linguistic practices of the relevant groups-either citizens at large or those learned in the law in the eighteenth century. The ambiguity could be resolved if evidence of usage confirms one of the readings suggested above-or, as may be the case, it establishes some other, slightly different meaning. 


\section{The Possibility of IrReducible Ambiguity}

The analysis so far has suggested that the original meaning of the phrase "natural born citizen" may be ambiguous, or that evidence of that meaning may be insufficient to resolve the ambiguity introduced by the passage of more than two centuries. Most originalists assume that constitutional ambiguities can usually be resolved by reference to the original public meaning in context. But what does originalism say about ambiguities that cannot be resolved in this way? What if the original meaning is itself ambiguous or if there is insufficient evidence to resolve an ambiguity?

It is at this point that "New Originalists," such as Keith Whittington and Randy Barnett, might suggest that "interpretation runs out," and a different modality of constitutional practice must be engaged-this is what New Originalists call constitutional construction. Although New Originalists agree on original public meaning as the correct account of constitutional interpretation, they disagree about the best approach to constitutional construction. Randy Barnett's distinctive theory of constitutional legitimacy sanctions a justice-enhancing account of constitutional construction. Keith Whittington has emphasized deference to democratic political processes. Jack Balkin suggests that construction should be guided by reference to the purpose of the constitutional provision at hand. Different approaches to constitutional construction might give different answers to the question whether McCain is eligible for the presidency.

\section{CONClusion}

The phrase "natural born citizenship" is semantically inaccessible to modern readers. Because this phrase violates the rule of compositionality, it must be understood as an idiom or term of art. For this reason, gleaning the meaning of the phrase requires us to investigate linguistic practice to recover the original meaning - the meaning of "natural born citizen" at the time of constitutional utterance. When we look for public meaning, we may discover that the division of linguistic labor in the late 18th century takes us to the shared understandings of those learned in the law. We may need to look to eighteenth century linguistic practice to make sense of a phrase that would otherwise be either mysterious or radically ambiguous. For this reason, the natural born citizen clause may illustrate what we might call the "inescapability of originalism": Some constitutional provisions only make sense after we turn our attention to the way language was used when they were framed and ratified. There is good reason to believe that the natural born citizen clause is one of these provisions.

But, from the fact that originalism is inescapable, it does not follow that originalism answers all constitutional questions. Grasping the original meaning of the natural born citizen clause may lead us to the conclusion that the constitutional text does not provide the answer to all of our questions about eligibility for the office of President. Constitutional practice may require both interpretation and construction: The original public meaning of the natural born citizen clause may not suffice to answer the question whether John McCain is eligible for the office of President of the United States. 
